\title{
The diagnostic accuracy of Sudoscan in TTR-FAP
}

\author{
Jose Castro ${ }^{2^{*}}$, Isabel Conceicao ${ }^{2}$, Isabel Castro ${ }^{1}$, Mamede de Carvalho ${ }^{2}$ \\ From First European Congress on Hereditary ATTR amyloidosis \\ Paris, France. 2-3 November 2015
}

\section{Introduction}

Small-fibre length-dependent sensory-motor and autonomic neuropathy is the hallmark of TTR-FAP.

SUDOSCAN was recently introduced as a quick and non-invasive method that measures electrochemical skin conductance (ESC) of palmar and plantar surfaces, through reverse iontophoresis. It has been described as a promising diagnostic tool in distal symmetric polyneuropathies, such as diabetic small fibre neuropathy.

\section{Objective}

To evaluate the diagnostic accuracy of Sudoscan in patients with TTR-FAP.

\section{Methods}

Forty stage I TTR-FAP patients were compared with 70 TTR-FAP asymptomatic carriers and 37 healthy controls, matched for age, gender and body-mass index. Inclusion criteria for TTR-FAP patients included normal sural nerve sensory action potential amplitude and plantar sympathetic skin response (SSR). Patients with diabetes were excluded. All subjects were assessed with Sudoscan in hands and feet, bilaterally.

\section{Results}

Feet ESC was significantly reduced in Stage I patients compared with asymptomatic carriers and controls $(57.8 \pm 24.3$ vs $76.5 \pm 7.8$ and $79.7 \pm 5.1 ; \mathrm{p}<0.000)$. Hands ESC did not show significant difference between groups.

Receiver operating characteristic curve analysis revealed an area under the curve of 0.80 for the plantar ESC.

A significant correlation was found between plantar and Sural nerve action potential amplitude $(0.320 ; \mathrm{p}<$ $0.001)$.

${ }^{2}$ Instituto de Medicina Molecular, Faculty of Medicine, Translational and Clinical Physiology Unit, 1600, Lisboa, Portugal

Full list of author information is available at the end of the article

\section{Conclusion}

Sudoscan seems to be a promising diagnostic tool in TTR-FAP patients with normal conventional nerve conduction studies and preserved plantar SSR. However, its predictive value is unknown.

\section{Authors' details}

'Centro Hospitalar Lisboa Norte - Hospital de Santa Maria, Department of Neurosciences, 1600, Lisboa, Portugal. ${ }^{2}$ Instituto de Medicina Molecular, Faculty of Medicine, Translational and Clinical Physiology Unit, 1600, Lisboa, Portugal.

Published: 2 November 2015

doi:10.1186/1750-1172-10-S1-P42

Cite this article as: Castro et al:: The diagnostic accuracy of Sudoscan in TTR-FAP. Orphanet Journal of Rare Diseases 2015 10(Suppl 1):P42.
Submit your next manuscript to BioMed Central and take full advantage of:

- Convenient online submission

- Thorough peer review

- No space constraints or color figure charges

- Immediate publication on acceptance

- Inclusion in PubMed, CAS, Scopus and Google Scholar

- Research which is freely available for redistribution
() Biomed Central
C Biomed Central

(c) 2015 Castro et al. This is an Open Access article distributed under the terms of the Creative Commons Attribution License (http:// creativecommons.org/licenses/by/4.0), which permits unrestricted use, distribution, and reproduction in any medium, provided the original work is properly cited. The Creative Commons Public Domain Dedication waiver (http://creativecommons.org/publicdomain/ zero/1.0/) applies to the data made available in this article, unless otherwise stated. 